\title{
REVIEW ON IMPACT OF CLIMATE CHANGE ON ETHIOPIA AGRICULTURE: CURRENT AND FUTURE PROSPECT
}

\section{Biftu Umer Mohammed}

Gambella University College of Agriculture and Natural Resource, Department of Plant Sciences, Gambella, Ethiopia

Email: biftuumer22@gmail.com

\begin{abstract}
As agriculture is much sensitive to climate and weather variables climate change has become one of the major challenges in maintaining agriculture productivity. This paper reviews impact of climate change on Ethiopian agriculture. Agriculture is the main sector of Ethiopian economy that contributes $50 \%$ of GDP. Currently agriculture, specially crop production in Ethiopia is affected by failure of rains, delay on onset of rainy season and high rate of evapo-transpiration due to increasing of temperature in the growing season this also continue for the future and had negative impact on the sector unless good adaptation strategies are forwarded.
\end{abstract}

\section{No: of References: 45}




\section{INTRODUCTION}

Green House Gases (GHGs) emission from anthropogenic activities now a day's causes worldwide warming and climate change. It has been taken into consideration as one of the destiny multifaceted catastrophe for the international surroundings and society on the way to have an effect on through changing in climatic variables such temperature, rainfall, soil quality, drought, hurricane surge and sea level (Ramlall, 2014). The world's climate has been changing for numerous thousand years. According to Brown and Crawford (2009) Seven thousand years ago, for example, the Sahara changed into a panorama of lakes and forests.

The influences of weather change together with growing international common temperature and changes in precipitation are undeniably clear with affects already affecting ecosystems, biodiversity and human systems in the course of the world. On pinnacle of this many scholars believe agriculture is the maximum susceptible area to climate alternate (Abate, 2009). Although, developing countries exceptionally depend on agriculture for their livelihoods (World Bank 2007). But, agriculture could be very much touchy to climate and weather variables like temperature, precipitation, mild and climate extremes which motive drought, flood and severe storms (Molva 2002).
Even though, its impact is excessive on agriculture there's variant in vulnerability depending on location, adaptive potential and different socio economic and environmental factors. For instance, in Europe, agricultural sector is thought to advantage from gradual climate alternate because of the carbon effect and the warming weather (Tol et al. 2000; McCarthy 2001; Kurukulasuriya and Rosenthal 2003). On the contrary, on continents along with Africa, continent that has contributed almost nothing to anthropogenic climate alternate, the effect is assumed to be enhanced. The dangers of global warming ought to jeopardize many years of improvement efforts, particularly in the poorest regions of our planet (Marius, 2009). This is attributed to the continent's low adaptive capability, over-dependence on agricultural sector, marginal weather and lifestyles of many other stressors (Collier et al. 2008; McCarthy 2001).

Agriculture contributes the spine of most African economies and is main contributor to GDP of the region. It bills for about a $3^{\text {rd }}$ of Africa's GDP, employs in many countries approximately $60-90 \%$ of the total labor force and is most important source of livelihood for poor people (EU, 2007). In addition most of poor Africans stay in rural areas, where they depend at once or indirectly on agriculture (Oyiga et al, 2011).

Although agriculture is the main zone of the Ethiopian economic system round $85 \%$ 
of the population is immediately supported through agricultural economy (Hamza and lyela,2012). Agriculture has been the mainstay of the financial system of Ethiopia's and will stay so in the future. It affords approximately half of the gross home product (GDP) and $85 \%$ of foreign exchange profits, Ethiopia's agriculture met almost the food wishes of the population, at least on the subsistence level. (CSA 2005, Sonneveld, 2002).

Ethiopia is hit harder than most countries by drought and its devastating consequences. Recurrent droughts have resulted in loss of life and property as well as the migration of people. Drought frequency is predicted to increase placing stress on already vulnerable production systems. The mainstay of the Ethiopian economy is rain-fed agriculture, which is heavily sensitive to climate variability and change (CSA, 2007).

Almost $80 \%$ of the population lives in rural areas and counting on crop production and keeping livestock as means of livelihood (Hamza and Iyela, 2012). This sector is dominated by small-scale mixed crop and livestock production, with very low productivity. the main factors liable for the low productivity include reliance on traditional farming techniques, soil degradation, poor complementary services like extension, credit, marketing, infrastructure also as climatic factors like drought and flood (Alene 2003; Yirga 2007). Ethiopia is among the foremost global climate change vulnerable countries in Africa thanks to its great reliance on climate sensitive sectors, particularly agriculture (NMA, 2007; Conway and Schipper, 2011; Rosell, 2011). Agricultural systems worldwide over the last 40 - 50 years have skilled the effect of the interacting driving forces of population increase, income growth, urbanization and globalization on food production, markets and consumption (Von Braun, 2007). to those forces are often added the dual elements of climate variability and global climate change which have an immediate effect on food production and food security (Parry et al., 2004). Climate variability, particularly rainfall variability and associated droughts are major causes of food insecurity and famine in Ethiopia (Demeke et al., 2011; Rosell, 2011; International Bank for Reconstruction and Development, 2006). Therefore, this review is concentrated on current and future impact of global climate change on Ethiopian agriculture.

\section{Climate of Ethiopia and climate variability}

Ethiopia may be a country with large heterogeneity in terms of its agro-ecology, even within smaller administrative units. supported this classification, the whole country falls into six major agro-ecological zones. These are Bereha (desert, below 500 $\mathrm{m}$ a.s.I.), Kolla (lowlands, 500-1,500 m a.s.I.), Weynadega (midlands, 1,500-2,300 m a.s.l.) and Dega (highlands, 2,300-3,200 m a.s.l.), Highdega (3,200-3,700 $m$ a.s.l.) and Wurch (above 3,700 $\mathrm{m}$ a.s.l.). The surveyed districts fall under three of those (Dega, Weynadega, Kolla). Kolla is characterized by yellow sandy soils and is suitable just for 2020 September Edition | www.jbino.com | Innovative Association 
acacia trees. Where moisture retention terraces are installed, however, it's suitable for the assembly of sorghum and ground nuts. Weynadega is characterized by light and red brown soils. the assembly environment is suitable for wheat, maize and teff (most popular cereal within the country). Maize and wheat, along side barley, also are widely grown in Dega and Highdega. The soils are typically brown and dark brown clay. The zones have two cropping seasons per annum (long and short rainy seasons). Mean annual rainfall varies widely, starting from about $1,200 \mathrm{~mm}$ over some pocket areas in Kolla to not up to $250 \mathrm{~mm}$. Mean annual temperature varies from about $12{ }^{\circ} \mathrm{C}$ over the highlands within the Dega zone to about $27{ }^{\circ} \mathrm{C}$ on the Kolla zone (Hurni 1998). Climatologically, October to January is that the season (the Bega season) while March to May constitutes a brief season (the Belg season). The main season, or Kiremt season, occurs between June and September, contributes $50-80 \%$ rather than annual precipitation, and is that the major source of water utilized in rain-fed agriculture.

Climate change is a change of climate which is attributed directly or indirectly to human activity. It alters the composition of the global and/or regional atmosphere and natural climate variability observed over comparable time periods. Climatic variability are the types of changes (temperature, rainfall, occurrence of extremes); magnitude and rate of the climate change that causes the impacts on the area of public health, agriculture, food security, forest hydrology and water resources, coastal area, biodiversity, human settlement, energy, industry, and financial services. Changes in physical and socio-economic system have been identified in many regions (UNFCCC, 2007). According to the Fourth Assessment Report of the Intergovernmental Panel on Climate Change (IPCC), the global average surface temperature is likely to rise by 1.8 degrees to 4.0 degrees Celsius by 2100 . The sea level may rise by 30 to 60 centimeters. Climate variability will increase almost everywhere. Northern latitudes will experience more rainfall; many subtropical regions will see less (IPCC, 2001).

Assortments of studies have investigated historical trends of climate change and variability in Ethiopia. For example, a $0.2^{\circ} \mathrm{C}$ to $0.28^{\circ} \mathrm{C}$ rise per decade in the average yearly maximum temperature between 1960 and 2006 was reported (Amsalu,2014; Keller, 2009), whereas, $0.37^{\circ} \mathrm{C}$ per decade increase was observed in the minimum temperature between 1951 and 2006 (McSweeney,2008). A outcrop suggests that Ethiopia will experience a $1.7^{\circ} \mathrm{C}-2.1^{\circ} \mathrm{C}$ increase in the mean temperature by 2050 (EPA, 2012). On the other hand, by using historical data of temperature and precipitation from 1971-2000 for selected stations in Ethiopia experienced year-toyear variation of rainfall for the period between 1951 to 2005 over the country expressed in terms of normalized rainfall anomaly averaged for 42 stations (NMA, 2007). The country during those periods 
(1951 to 2005) has practiced both dry and wet years over the last 54 years. These changes in the physical environment are expected to have an undesirable effect on agricultural production, including staple crops such as wheat and maize. Trend analysis of annual rainfall in Ethiopia shows that rainfall remained more or less constant when averaged over the whole country while a declining trend has been observed over the Northern and Southwestern Ethiopia (IPCC, 2007).

Habtemariam et al.,(2016); Abrha and Simhadri (2017) used binary logit/probit/recursive bivariate probit model to examine factors impeding households' perception of climate change and their link with meteorological data. In the study they tried to document the trends in rainfall and temperature data at national, regional, and local levels. They reported complex patterns in the climate parameters.

Similar study by Befikadu et al.(2019) on study of Climate Variability and Farmers' Perception in Southern Ethiopia they observed high variability in the ATmax over the 32years. In addition, the year 2012 is observed as the hottest year in AEZs while 1989 was the lowest ATmax year for the midland and lowland AEZs. Farther more, Mengistu et al. (2014) observe relatively cold years in the1980sand warm years from the early 1990s to the 2000s on Upper Nile basin.

The agro-ecological setting of farmers influences the perception of farmers to global climate change. A study by Diggs (1991) revealed that farmers living in drier areas with more frequent droughts are more likely to explain the global climate change to be warmer and drier than farmers living during a relatively wetter area with less frequent droughts. In Ethiopia, lowland areas are drier with higher drought frequency than other areas (Belay et al. 2005). Thus, it's hypothesized that farmers living in lowland areas are more likely to perceive global climate change as compared to midland and highlands.

Currently most researcher observed similar trends on climate variability in Ethiopia. supported this they acknowledged "decrease in the number of rainy days with an increase in the mean rainfall per rainy day in the Kiremt" (Ethiopian summer) rainfall for watersheds located within the south western and central parts of the country (Osman and Saverborn 2002, Cheung et al. 2008). Also the mean annual temperature has been increased at a mean rate of $0.2^{\circ} \mathrm{C}$ per decade (NMA, 2007), Northern a part of the country specially Amhara region the Belg and the Bega rainfalls are found far more variable (>30\%) than the Kiremt rainfall. Similarly, Woldeamlak and Conway (2007) by analyzing rainfall data from 12 stations in drought-prone areas of Amhara Region, Ethiopia they observed that Belg and Bega rainfalls are more variable than Kiremt rainfall. In study on trends and spatial distribution of annual and seasonal rainfall in several parts of Ethiopia using data from 
134 stations in 13 watersheds between 1960 and 2002 by Wing et al. (2008) they noted Significant decline in June to September rainfall (Kiremt). Generally, the rainfall within the Amhara region is characterized by sporadic fluctuation of wet and dry years (Dereje et al. 2012).

\section{Current impacts of climate change on agriculture}

Agriculture in Ethiopia is heavily dependent on rain. Its geographical location and topography and a low adaptive capacity, make the country highly vulnerable to the adverse impacts of climate change. Poverty in Ethiopia is a chronic problem and about two-thirds of its 72 million people live on less than $\$ 2$ a day income (World Bank 2008). A recent mapping on vulnerability and poverty in Africa put Ethiopia as one of the countries most vulnerable to climate change with the least capacity to respond (Orindi et al. 2006; Stige et al. 2006)

Crop production in Ethiopia is affected by failure of rains or occurrence of successive dry spells during the growing season. Food shortages resulting from adverse weather conditions are not new in Ethiopia. However, food shortages have increased in severity, with frequent shortages in recent years. The degree of vulnerability varies between the different regions based on wealth, technology, availability of infrastructure and institutions, potential for irrigation, and literacy rates. In general, vulnerability to climate change in Ethiopia is highly related to poverty. Integrated rural development initiatives aimed at reducing poverty can play a role in increasing adaptive capacity to climate change. The major effects of climate change on crop production include changes in regular crop planting times, length of growing season and shift in crop type or cultivars. crop production in the country is highly correlated to the rainfall patterns. Rainfall variability and recurrent drought are leading to frequent crop failures, loss of life and property.. Climate change exhibited through higher temperatures, rainfall variability, water scarcity, flooding, drought and displacement, negatively impacts agricultural production and causes breakdown in food systems (ECA, 2016).

The Current climate change has many impacts on different agricultural activity. The warming and rainfall trend insist its impact on crop production with raising the evaporative demand. On the other hand, this situation has created good opportunities for weeds to stay in the cropping land so that it latter emerges with crops and out-compete them. Erratic precipitation period has also increased an opportunity for crop pests (Abate,2009). Drought and delay in the onset of rain led to poor grass regeneration/forage deficit, water shortage and heat stress on livestock, and consequently increased the mortality of the livestock, vulnerability to diseases and physical deterioration due to long distance travel for water and pastures (West-Arsi Zone FS-DPPO 2008). 
Also, Deressa et al., (2008) conducted an integrated quantitative vulnerability assessment for seven Regional States of the total eleven regions of Ethiopia by using biophysical and social vulnerability indices of Ricardian approach. The study has found that decline in precipitation and increase in temperature are both damaging to Ethiopian agriculture. Unseasonal rainfall also results in seed drop, ripened crops germination, crop desiccation delay and harvested crops spoilage. In 2008 unseasonal rain cause serious loss in Meher crop in mid and lowlands (Abate,2009).

According to Seid et al.,(2016) Assosa District, Western part of Ethiopia is highly affected by climate change and variability. As Temesgen et al. (2008) indicated most significant climate change impact in the western part of Ethiopia is due to drought and flood. The overall natural resources base of the region is highly degraded. This initial potential together with the current global climate change aggravates the vulnerability of the community to climate change impacts. Various reports agree that the region has been facing droughts that have occurred in the country indicating susceptibility of the region to climate change. Thus, people in the region are facing a variety of shocks and become vulnerable.

Gregory et al., (1999) reported a decreased crop duration (and hence yield) of wheat as a consequence of warming and a reduction in the yield of rice of about $5 \%$ per ${ }^{\circ} \mathrm{C}$ rise above $32^{\circ} \mathrm{C}$.
Using a simulation model of production for cropping systems, Tubiello et al., (2000) showed that the combined effect of increased carbon dioxide and climate change will reduce crop yields by $10-40 \%$ if current management practices were not amended. Therefore new cropping systems which are resilient and adaptable to changing climatic conditions are required. More recently, elements of crop adaptation to extreme weather events have been explored with genotypic variation and adaptability to cope with several of the negative impacts on an adapted productivity (Fuhrer, 2006). While Ethiopia has always suffered from great climatic variability, including droughts that have contributed to hunger, climate change is set to make the lives of the poorest even harder. Small scale farmers are more vulnerable and likely to bear the brunt of the negative impacts of climate change. This is partly due to the traditional management practices that they adopt. The expected crop yield losses due to climate change will therefore impact on their already low level of income, and left without any alternative source of income, the situation would lead to increased poverty and food insecurity.

According to the study of Tagel and Anne (2013) in tigray, northern part of Ethiopia they observed that uneven distribution of rainfall. Also the climate is characterized by large spatial variations which range from about 1000-1260 mm year-1 in some pockets areas in the Southwest to about less than $300 \mathrm{~mm} \mathrm{yr}^{-1}$ in the Northeast 2020 September Edition | www.jbino.com | Innovative Association 
lowlands. As result most of the drought events have been geographically concentrated in the eastern and southern parts of Tigray, with some of the districts experiencing high frequency of droughts. Also in terms of temperature the spatial distribution of temperature shows an increasing minimum and maximum temperature pattern from southern to the western parts of the region.

\section{Future impact of global climate change in Ethiopia}

Understanding the variability and expected future changes of climate, particularly characteristics of rainfall, temperature and evapo-transpiration is crucial for planning and designing appropriate adaptation strategies. Warming is projected throughout the continent altogether regions supported the Projections warming in Africa are going to be greater than the worldwide annual mean, with a mean increase of $3-4^{\circ} \mathrm{C}$ over subsequent century (Boko et al, 2007). The southern region and its western margins are expected to ascertain rainfall decrease, especially during the winter harvest months. East Africa is probably going to ascertain a rise in annual mean rainfall, whereas projections are uncertain for the Sahel, Guinean Coast, and southern Sahara. Across Sub-Saharan Africa, it's expected that when rain does fall, it'll occur increasingly in high intensity, sporadic rain events (Christensen et al,2007). The global climate change impact on agriculture is believed to be stronger in Sub-Saharan Africa
(Kurukulasuriya \& Mendelsohn 2007). Future impacts are projected to worsen because the temperature continues to rise and as precipitation becomes more unpredictable. Among the various adverse impacts of global climate change, the danger to agriculture is taken into account most significant (Kurukulasuriya and Mendelsohn 2008a, b; Seo et al. 2009)

Contribution of Ethiopia to global greenhouse gas emissions is negligible, but it is affected by the adverse impacts of climate change brought by the carbonintensive development paths of rich countries over the past century. According to the country's First National Communications to the UNFCCC, temperature across the country could rise by between 0.5 and $3.6^{\circ} \mathrm{C}$ by 2070 . The annual average temperature during 2070 2090 is projected to be $26.92^{\circ} \mathrm{C}$, up $3.84^{\circ} \mathrm{C}$ on the 1960-90 average whilst average daily rainfall will reduce by $3.5 \%$ by the end of the century (Hassan, 2006).

The increase in minimum temperatures is more pronounced with roughly $0.4^{\circ} \mathrm{C}$ per decade. Precipitation, on the opposite hand, remained fairly stable over the last 50 years when averaged over the country. However, the spatial and temporal variability of precipitation is high. Thus, large-scale trends don't necessarily reflect local conditions. The projected increases within the inter annual variability of precipitation together with the warming will likely cause increases within the occurrence of droughts. Furthermore,

$$
2020 \text { September Edition | www.jbino.com | Innovative Association }
$$


heavy rains and floods are projected to extend also (Marius, 2009).

Studies by the National Meteorological Services of Ethiopia indicate that the typical minimum and maximum temperatures are increasing by about $0.25^{\circ} \mathrm{C}$ and $0.1^{\circ} \mathrm{C}$, respectively, over the past decade, whereas the rainfall is characterized by very high levels of variability over the past 50 years (Tadege, 2007). Although models predicting precipitation give contradictory suggestions of accelerating or decreasing precipitation, most climate prediction models agree that temperatures in Ethiopia will increase over the approaching years (Strzepek and Cluskey 2006). Additionally, forecasts by Tadege (2007) indicate that temperatures in Ethiopia will increase within the range of $1.7-2.1^{\circ} \mathrm{C}$ by the year 2050 and $2.7-3.4^{\circ} \mathrm{C}$ by the year 2080. Moreover, studies show that the frequency and spatial coverage of drought have increased over the past few decades and this is often expected to continue within the future (Lautze et al. 2003).

In some regions of Africa the losses in cropland area are likely to occur at a way faster rate, with northern and eastern Africa losing up to fifteen of their current cropland area within subsequent 30 years approximately. Although western and southern Africa will experience some gains as a results of anticipated increases in rainfall during the sooner period of the century, these benefits are going to be proved by some losses because the years pass (Lotsch 2007). Hulme et al., (2000) also showed that rainfall decreases 'significantly' in June-July-August (JJA) over parts of the Horn of Africa which is that the main crop cultivation season in Ethiopia. Using the AEZ model, Shah et al. (2008) two-thirds of the worldwide land surface will suffer severe constraints for rain-fed crop cultivation thanks to unfavourable temperatures, precipitations, topography or soil quality. In SSA, their assessment revealed that arable land will suffer severe environmental constraints, preventing crop production in Eastern Africa (by up to 2.4\%); Central African Republic (by up to $1.2 \%$ ) and Western Africa (by up to $1.7 \%$ ). Southern Africa are going to be the foremost severely affected region with about $11 \%$ of its total acreage $(265$ million hectares) in danger of being lost for crop production thanks to environmental constraints induced by global climate change (Fischer et al. 2005; Shah et al. 2008).

Similar to other African countries, Ethiopia is dramatically susceptible to future global climate change (Conway and Schipper, $2011)$. Drought remains the country's major hazard, with floods following in second place. Recurrent droughts form the main threat to rural livelihoods and food security within the country. A marked increase in both size and frequency has recently become apparent (Ferris-Morris, 2003). Funk et al. (2005) reported that rainfall in Ethiopia is predicted to say no within the future and also become more irregular. A 
study by UNDP (2008) also underline that global climate change in Ethiopia could lead on to extreme temperatures and rainfall events, also causes more heavy and extended droughts and floods. Accordingly, considering the very fact that the country is very obsessed in to the agricultural sector for income and food security, erratic monsoon precipitation would adversely affect the lives perhaps the bulk of the populations (Haile, 2005). Dercon (2004) reported that in Ethiopia, a season with starkly reduced rainfall depressed consumption even after four to 5 years. Furthermore, the country's agroecosystem is additionally sensitive to rainfall and has low adaptive capacity to reply to damages. As a result, a small change in climate will have an outsized impact on the socio-economic activity of the country (Fraser, 2007). Despite agriculture being given an overriding emphasis as a core sector to bring future sustainability to the country, the world is recently challenged by global climate change and variability. global climate change and associated risks are therefore expected to possess serious consequences for the country's economy, and agriculture and food security .

\section{Conclusion}

This paper reviewed the existing literature on the current and future impact climate changes in on agricultural production. Ethiopia contribution to global climate change is negligible, but it is affected by the adverse impacts of climate change brought by the carbon-intensive development paths of rich countries over the past century.

Currently there is changes in average temperature, intensity of rainfall and distribution that are capable of causing natural hazard such as droughts and floods. In addition, for the future climate change will negatively affect crop production potential and reduce yields considerably and increase risk of famine. Therefore, Government and development partners must support climate change adaptation and disaster risk-reduction planning by taking into account.

\section{References}

Abate Feyissa 2009. Climate Change Impact on Livelihood, Vulnerability and Coping Mechanisms: A Case Study of West-Arsi Zone, Ethiopia. MSc. Thesis, Lund University, Sweden.

Abrha M. G. and S. Simhadri, 2017. "Local climate trends and farmers' perceptions in Southern Tigray, Northern Ethiopia,"American Journal of Environmental Sciences, vol. 11, no. 4,pp. 262-277,

Alene, A.D. (2003). Improved production technology and efficiency of small holder farmers in Ethiopia: extended parametric and non-parametric approaches to production efficiency analysis. PhD Thesis, University of Pretoria, South Africa.

Amsalu A., W. Negatu, N. Canales Trujillo et al., Climate Finance in Ethiopia, 2014, https://www.odi.org/sites/odi.org.uk/files/o 
diassets/publications-opinion-

files/8995.pdf.

Boko, M.; Niang, I.; Nyong, A.; Vogel, C.; Githeko, A.; Medany, M. Osman-Elasha, B. Tabo, R.; Yanda, P. Africa. In Proceedings of the Working Group II Report -Impacts, Adaptation and Vulnerabilityll; Parry, M.L., Canziani, O.F., Palutikof, J.P., van der Linden, P.J., Hanson, C.E., Eds.; Cambridge University Press: Cambridge, UK, 2007.

Central Statistical Authority (CSA), (2007). Statistical Tables for the 2007 Population and Housing Census of Ethiopia. Central Statistical Agency, Addis Ababa

Christensen, J.; Hewitson, B.C.; Mearns, L.O. Regional Climate Projections. In Climate Change 2007: The Physical Science Basis: Contribution of Working Group I to the Fourth

Assessment Report of the Intergovernmental Panel on Climate Change; Solomon, S., Qin, D., Manning, M., Eds.; Cambridge University Press: Cambridge, UK, 2007.

Collier, P., Conway, G. \& Venables, T., 2008. Climate change and Africa. Oxford Review of Economic Policy, 24(2), 337.

Deressa, T., Hassan, R.M. \& Ringler, C., 2008. Measuring Ethiopian Farmers' Vulnerability to Climate Change Across Regional States. International Food Policy Institute.

Ethiopia Climate Action (ECA) report for 2016
Ethiopian Environmental Protection Agency (EPA), , 2012. "National report of Ethiopia," in the United Nations Conferenceon Sustainable Development (Rio 20+), Ethiopian Environmental Protection Agency, Addis Ababa, Ethiopia

EU.2007. advanced African agriculture : proposal for continental and regional level cooperation on agricultural development in Africa. DG Development Unite B2polocies for sustanble management of natural Resource.

Fuhrer, J. (2006). Agricultural Systems: Sensitivity to Climate Change, $C A B$ Reviews: Perspective in Agriculture, Veterinary Science, Nutrition and Natural Resources, No 052.

Gregory, P. J., Ingram, J. S. I, Cambell, B., Gourdriaan, J., Hunt, L. A.,Landsberg, J. J., Li nder, S., Stafford Smith, M., Sutherst, R. W., and Valentin, C. 1999. Managed Production Systems. In: Walker, B., Steffen, W., Candell, J, and Ingram, J. S. I.(eds). The Terrestrial Biosphere and Global Change: Implications for Natural and Managed Systems. Cambridge University Press, Cambridge, Pp 229- 270.

Habtemariam L. T., M. Gandorfer, G. A. Kassa, and A. Heissenhuber, 2016. "Factors influencing smallholder farmers' climate change perceptions: a study from farmers in Ethiopia," Environmental Management, vol. 58, no. 2, pp. 343-358,

Hamza, I.A. and lyela A.2012, land use pattern, climate change, and its implication for food security in ethiopia: a 
review. Ethiopian Journal of Environmental Studies and Management Vol. 5 No.1 2012

Hassan, R. (2006). Climate change and African agricultures, Policy Note. Human Development Report, 2007/2008. Climate Change and Human Development in Africa: Assessing the Risks and Vulnerability of Climate Change in Kenya, Malawi and Ethiopia. By IGAD Climate Prediction and Applications Centre (ICPAC).

Hulme, M., Doherty, R., Ngara, T., New, M., \& Lister, D. (2000). African climate change: 1900-2100. Climate Research, 17, 145-168.

Hurni H (1998) Soil conservation research programme Ethiopia: research report on agroecological belts of Ethiopia. Addis Ababa

IPCC (2007). Climate Change 2007: Synthesis Report. Contribution of Working Groups I, II and III to the Fourth Assessment Report of the Intergovernmental Panel on Climate Change. Geneva.

IPCC (2001). Climate Change 2001: Impacts, Adaptation, and Vulnerability. Contribution of Working Group II to the Third Assessment Report. Cambridge, University Press, Cambridge, UK.

Keller M.,2009 Climate Risks and Development Projects, Assessment

Kurukulasuriya, P., \& Mendelsohn, R. (2008a). How will climate change shift agro-ecological zones and impact African agriculture? World Bank Policy Research Working Paper 4717. World Bank, Washington D.C, USA.

Lautze, S., Aklilu, Y., Raven Roberts, A., Young, H., Kebede, G. and Leaning, J. (2003). Risk and Vulnerability in Ethiopia: Learning from the Past, Responding to the Present, Preparing for the Future. Report for the U.S. Agency for International Development. Addis Ababa, Ethiopia: USAID.

McCarthy, J.J., 2001. Climate change 2001: impacts, adaptation, and vulnerability: contribution of Working Group II to the third assessment report of the Intergovernmental Panel on Climate Change, Cambridge University Press.

McSweeney C., M. New, and G. Lizcano, 2008, "UNDP climate change Country profiles Ethiopia," http://countryprofiles.geog.ox.ac.uk.

Mengistu D., W. Bewket, and R. Lal, 2014. "Recent spatiotemporal temperature and rainfall variability and trends over the upper blue nile river basin, Ethiopia," International Journal of Climatology, vol. 34, no. 7, pp. 2278-2292,

Molua, L. E. (2002). Climate variability, vulnerability and effectiveness of farm-level adaptation options: The challenges and implications for food security in Southwestern Cameroon. Environment and Development Economics, 7(3), 529-545.

NMA (National Meteorological Agency), (2007). National Meteorology Agency: Final jbino.com | Innovative Association 
Report on Evaluation Criteria for Identifying High Priority Adaptation Activities prepared by $B$ and $M$ Development Consultants for NMA. Addis Ababa, Ethiopia.

\section{Oyiga Benedict, Mekbib Haile and} Christine Waschkeit, 2011. Implication of climate change on crop yield and food accessibility in sub-saharan Africa. Interdisciplinary term paper,ZEF doctoral studies program.

Parry, M. L., Rozenweig, C., Iglesias, A., Livermore, M., and Fischer, G. (2004). Effect of Climate Change on Global Food Production under SRES Emissions and Socioeconomic Scenarios, Global Environment Change, 14, 53-67.

Ramlall, I. 2014. Gauging the impact of climate change on food crops production in Mauritius. Int. J. Climate Change Strat. Manage. 6 (3): 332-355.

Report for a Community-Level Project in Guduru, Oromiya,Ethiopia. Bread for All, https://www.iisd.org/cristaltool/documents

/BFA-Ethiopia-Assessment-Report-Eng.pdf.

\section{Seid Sani1, Jema Haji and Degye Goshu} 2016. Climate Change Adaptation Strategies of Smallholder Farmers: The Case of Assosa District, Western Ethiopia. Journal of Environment and Earth Science 6(7), 915

Seo, N., Mendelsohn, R., Dinar, A., Hassan, R., \& Kurukulasuriya, P. (2009). A Ricardian analysis of the distribution of climate change impacts on agriculture across agro-ecological zones in Africa.
Environmental Resource Economics, 43, 313-332. doi:10.1007/s10640-009-9270-z.

Sonneveld, B. G. J. S. (2002). Land Under Pressure. The Impact of Water Erosion on Food production in Ethiopia, Shaker Publishing, Netherlands.

Strzepek, K. and M Ccluskey, A. (2006). District Level Hydro-climatic Time Series and Scenario Analysis to Assess the Impacts of Climate Change on Regional Water Resources and Agriculture in Africa. CEEPA Discussion Paper 13. Pretoria, South Africa: Centre for Environmental Economics and Policy in Africa.

Tadege, A. (2007). Climate Change National Adaptation Program of Action (NAPA) of Ethiopia. Addis Ababa, Ethiopia: NMS (National Meteorological Agency: Federal Democratic Republic of Ethiopia, Ministry of Water Resources).

Tagel Gebrehiwot and Anne van der Veen 2013, Assessing the evidence of climate variability in the northern part of Ethiopia Journal of Development and Agricultural Economics 5(3), pp. 104119

Temesgen D., R.M. Hassan, A. Tekie, Y. Mahmud and C. Ringler, 2008. Analyzing the determinants of farmers' choice of adaptation methods and perceptions of climate change in the Nile Basin of Ethiopia. IFPRI Discussion Paper, September, 2008.

Tubiello, F. N., Donatelli, M., Rozenweig, C. and Stockle, C. O. (2000). Effect of Climate Change and Elevated $\mathrm{CO} 2$ on Cropping 
Systems: Model Prediction, Environmental Journal of Agronomy, 13,179-189

UNFCCC, (2007). Climate Change: Impacts, Vulnerabilities and Adaptation in Developing Countries.

Von Braun, J. (2007). The World Food situation: New Driving Forces and Required Actions. International Food Policy Research Institute, Washington D. C. USA.
West-Arsi Zone FS-DPPO, 2008. Emergency Food Security Assessment: Siraro District, Shashamane, Ethiopia.

Yirga, C.T. (2007). The dynamics of soil degradation and incentives for optimal management in Central Highlands of Ethiopia. PhD Thesis, Department of Agricultural Economics, Extension and Rural Development, University of Pretoria, South Africa. 